\title{
Aggregations of the jellyfish Aurelia labiata: abundance, distribution, association with age-0 walleye pollock, and behaviors promoting aggregation in Prince William Sound, Alaska, USA
}

\author{
Jennifer E. Purcell ${ }^{1, *}$, Evelyn D. Brown ${ }^{2}$, Kevin D.E. Stokesbury ${ }^{2, * *}$, \\ Lewis H. Haldorson ${ }^{3}$, Thomas C. Shirley ${ }^{3}$ \\ ${ }^{2}$ University of Maryland Center for Environmental Science, Horn Point Laboratory, PO Box 775, Cambridge, \\ Maryland 21613, USA \\ ${ }^{2}$ Institute of Marine Science, University of Alaska-Fairbanks, Fairbanks, Alaska 99775-7220, USA \\ ${ }^{3}$ Juneau Center, School of Fisheries and Ocean Sciences, University of Alaska-Fairbanks, Juneau, Alaska 99801, USA
}

\begin{abstract}
Aurelia labiata medusae occurred in aggregations with hundreds to millions of jellyfish. The aggregations were widely distributed in inlets of Prince William Sound (PWS). Alaska. Aerial surveys of PWS in May to August in 1995, 1996, and 1997 showed marked interannual variation in the numbers of aggregations observed, from a minimum of 38 in 1997 to a maximum of 557 in 1996. Acoustic surveys showed that the aggregations extended from near-surface $(0$ to $5 \mathrm{~m})$ to $15 \mathrm{~m}$ depth. Schools of young-of the-year walleye pollock Theragra chalcogramma were associated with $A$. labiata, both within and below the aggregations. All seine catches that contained juvenile pollock also contained jellyfish. Medusa swimming was analyzed from underwater videotapes in order to elucidate how aggregations might be formed and maintained. Medusae did not swim in circles in the aggregations. Medusae all swam vertically in the same direction, either up or down, in crowded parts of the aggregations, suggesting that they had become concentrated in flow features, like convergences, in the water column. Reduced swimming, due primarily to frequent collisions among medusae in the aggregations, also may have caused the medusae to become concentrated. The potential advantages of aggregation include increased fertilization success, retention near shore where planula settlement sites and zooplankton prey may be more abundant, retention in convergences where zooplankton are concentrated, and reduced predation.
\end{abstract}

KEY WORDS: Scyphozoa - Aurelia A Aerial surveys · Acoustics - Underwater video - Swimming Aggregation. Theragra chalcogramma

\section{INTRODUCTION}

Aurelia aurita, commonly called the 'moon jelly', is a cosmopolitan scyphomedusan occurring between $70^{\circ} \mathrm{N}$ and $40^{\circ} \mathrm{S}$ (reviewed in Möller 1980). It is undoubtedly the most studied jellyfish in the world, and several

-E-mail: purcell@hpl umces.edu

- Present address: Center for Marine Science and Technology, University of Massachusetts, Dartmouth, 706 Rodney French Blvd., New Bedford, Massachusetts 02744-1221, USA recent ecological studies exist from many countries (e.g. Grøndahl 1988, Båmstedt 1990, Hay et al. 1990, Lucas \& Williams 1994, Olesen et al. 1994, Sullivan et al. 1994, Behrends \& Schneider 1995, Nielsen et al. 1997. Toyokawa et al, 1997). Great numbers of $A$. aurita medusae often occur in semi-enclosed bays and inlets, where they have been shown to reduce zooplankton and ichthyoplankton densities and change zooplankton species compositions (Möller 1980, Olesen et al. 1994, Behrends \& Schneider 1995, Schneider \& Behrends 1998). 
On the Pacific coast of North America, it has been recognized recently that 2 species of Aurelia occur: $A$. aurita, which may have been introduced into San Francisco Bay, and A. labiata, which appears to be the native species (Greenberg et al. 1996, Wrobel \& Mills 1998). Because recent papers have incorrectly identified the species present in Alaskan and British Columbian waters as A. aurita (e.g. Hamner \& Schneider 1986, Strand \& Hamner 1988, Hamner et al. 1994), and both species form aggregations, we will use Aurelia spp. when appropriate. Although $A$. labiata is the species present along the northern Pacific Coast, $A$. aurita is the species in all other locations cited.

Aurelia spp. medusae have been reported in discrete, high-density aggregations in many locations (Yasuda 1969, Möller 1980, Hernroth \& Grøndahl 1985, Papathanassiou et al. 1987, Hamner et al. 1994, Toyokawa et al. 1997). The factors that lead to formation of aggregations are unknown, but it is likely that jellyfish react behaviorally to physical conditions in the water column. Aurelia spp. are sometimes found at the surface in convergences between Langmuir circulation cells (Hamner \& Schneider 1986, J.E.P. unpubl. data). In Saanich Inlet, British Columbia, Canada, medusae swam towards the southeast in sunlight, regardless of the sun's position, and aggregated along the eastern shore of the inlet (Hamner et al. 1994). Most jellyfish in those aggregations occurred in the surface $2 \mathrm{~m}$, and reached densities of nearly 75 medusae $\mathrm{m}^{-3}$. Acoustical records at 50 and $200 \mathrm{kHz}$ were used to describe the circular to eliptical aggregations in Tokyo Bay, Japan, which began 6 to $8 \mathrm{~m}$ below the surface and reached depths of 16 to $20 \mathrm{~m}$ (Toyokawa et al. 1997).

Aggregations have been described for some other scyphomedusan species, Stomolophus meleagris, Pelagia noctiluca, Phyllorhiza punctata, Linuche unguiculata, Cotylorhiza tuberculata, and Chrysaora fuscescens (Shanks \& Graham 1987, Malej 1989, Garcia 1990, Larson 1992, Kikinger 1992, Graham 1994). It should be noted that other large medusae present in PWS (Cyanea capillata, Aequorea aequorea var. albida) were not observed in near surface aggregations. Occasional large seine catches of $A$. aequorea suggested that they may occur in localized high densities; however, they were not observed by video in aggregations (J.E.P. pers. obs.)

The relationships between jellyfish and fish have been of particular interest because of the potential effects on commercially important fisheries. These interactions include predation on ichthyoplankton by jellyfish (reviewed in Purcell 1985, 1997, Arai 1988), potential competition between jellyfish and zooplanktivorous fish and fish larvae for prey (reviewed in Arai 1988, Purcell 1997), predation by fishes on medusae (reviewed by Arai 1988, Ates 1988, Harbison 1993), jel- lyfish being intermediate hosts for fish parasites (Arai 1988), and commensal associations between fish and medusae (reviewed in Mansueti 1963). The effects of medusae on fish may be negative (predation, competition, parasite transmission) or positive (food, protection). Jellyfish can also be detrimental to fisheries directly (Hay et al. 1990),

Juveniles of several fish species are known to associate with individual scyphomedusae (reviewed by Mansueti 1963). Young-of-the-year walleye pollock Theragra chalcogramma in Alaskan waters swim among the tentacles of Cyanea capillata and Chrysaora melanaster (van Hyning \& Cooney 1974, Brodeur 1998). Brodeur (1998) used an ROV and observed up to 5 walleye pollock with $C$. capillata and up to 30 with C. melanaster at depths of 30 to $40 \mathrm{~m}$ during the day. Juveniles of several fish species have been seen under the swimming bell of Aurelia aurita medusae: cods Gadus spp., haddock Melanogrammus aeglefinus, scads Trachurus spp., bluntnose jacks Hemicarnax amblyrhynchus, and bumpers Chloroscombrus chrysurus (reviewed by Mansueti 1963)

Walleye pollock are an important commercial species in Alaskan waters (Springer 1992) and the juveniles are primary forage fish for sea birds, marine mammals and fish including mature pollock (Clausen 1983, Hatch \& Sanger 1992, Livingston 1993). Walleye pollock congregate and spawn in deep water in midMarch to early April and the larvae occupy the upper $50 \mathrm{~m}$ of the water column in mid-April to mid-May (Hinckley et al. 1991, Kendall et al. 1996). Walleye pollock metamorphose into juveniles in late June (>22 mm standard length; Hinckley et al. 1991, Kendall et al. 1996). In Prince William Sound (PWS), Alaska, juvenile walleye pollock are second only to juvenile Pacific herring Clupea pallasi in abundance near shore (Stokesbury et al. 2000).

PWS has been the location of intensive ecological research following the 'Exxon Valdez' oil spill in 1989. It is a complex fjord-type estuary (Schmidt 1977) located on the northern margin of the Gulf of Alaska at $60^{\circ} \mathrm{N}, 146^{\circ} \mathrm{W}$, covering about $8800 \mathrm{~m}^{2}$ and having $3200 \mathrm{~km}$ of shoreline (Grant \& Higgens 1910) (Fig. 1). Many of the marine birds and mammals whose populations were injured by the oil spill feed on forage fish (herring Clupea pallasi, sandlance Ammodytes hexapterus, capelin Mallotus villosus, and walleye pollock). The research presented here is part of 2 multi-investigator projects-SEA (Sound Ecosystem Assessment) and APEX (Alaska Predator Ecosystem eXperiment) that assessed forage fish distribution and abundance using aerial surveys and acoustics, with seining and underwater video for target verification. Aggregations of Aurelia labiata were clearly visible during the aerial and acoustic surveys. Schools of young-of-the-year 

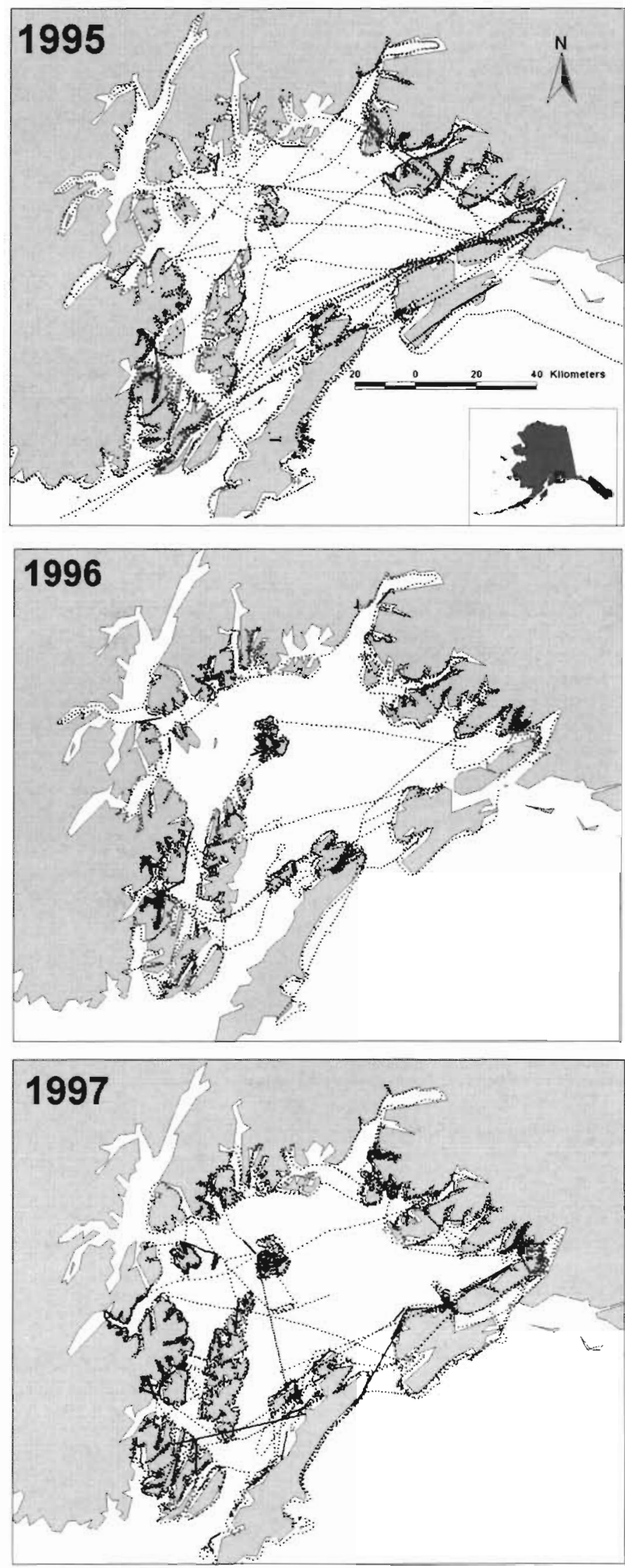

(age-0) walleye pollock were sometimes observed within and beneath those aggregations. Here, we report the distribution and abundance of $A$. labiata aggregations, their association with age- 0 pollock, and behaviors of the jellyfish in the aggregations that might explain their formation and maintenance.

\section{MATERIALS AND METHODS}

Distribution and abundance of Aurelia labiata aggregations. Monthly broadscale aerial surveys were conducted from March through August in 1995, May through August in 1996, and June and July in 1997 (see Brown et al. 1999) (Fig. 1). A total of $14232 \mathrm{~km}^{2}$ ground surface area was covered during broadscale surveys and the surface area flown per month was variable, ranging from $244 \mathrm{~km}^{2}$ in August 1996 to a high of $2009 \mathrm{~km}^{2}$ in July 1996 (Fig. 2). The survey design was a modified line transect associated with the nearshore, although we sampled offshore areas when crossing bays and bodies of water to reach other shorelines. An altitude-dependent visual swath was established based on ability to observe fish schools and jellyfish aggregations between 20 and 40 degrees measured from the wing; however, survey altitude was generally established at 274 to $366 \mathrm{~m}$. Both flight path (transect) and targets were recorded during the survey. A handheld GPS connected to a lap top computer with a flight log program recorded latitude, longitude, and time of day in $2 \mathrm{~s}$ intervals and logging was interrupted in order to record targets. Therefore the target location was associated with the coordinates prior to the brief interruption of logging.

The large, white, round-to-elongate aggregations of Aurelia labiata medusae were clearly visible from the aircraft and easily enumerated by aerial survey (Fig. 3). The shapes of the aggregations, aggregation counts and surface area estimates (by size category) were recorded during each survey. Size categories were established using a sighting tube to calibrate the size ranges. The sighting tube was constructed of PVC pipe with a grid drawn on mylar on the end. The tube was calibrated for ground distance covered by reference line $(X)$ for any survey altitude, when length of the grid reference line $(L)$, focal length

Fig. 1. Maps of Prince William Sound with flight paths of broadscale aerial surveys in July 1995, 1996, and 1997 


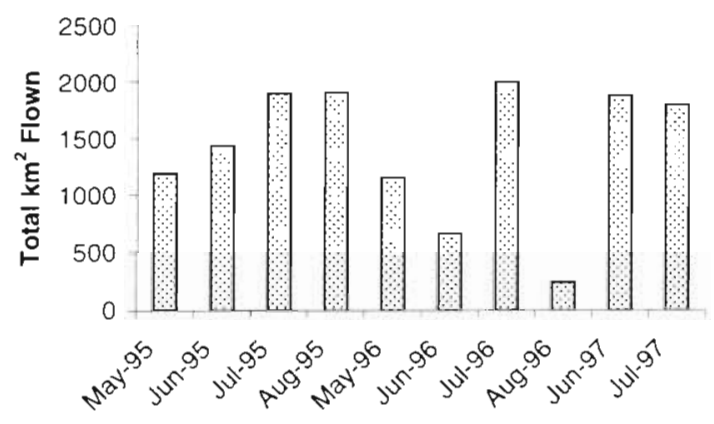

Fig. 2. Variation in surface area covered in aerial surveys of Prince William Sound during 1995, 1996, and 1997

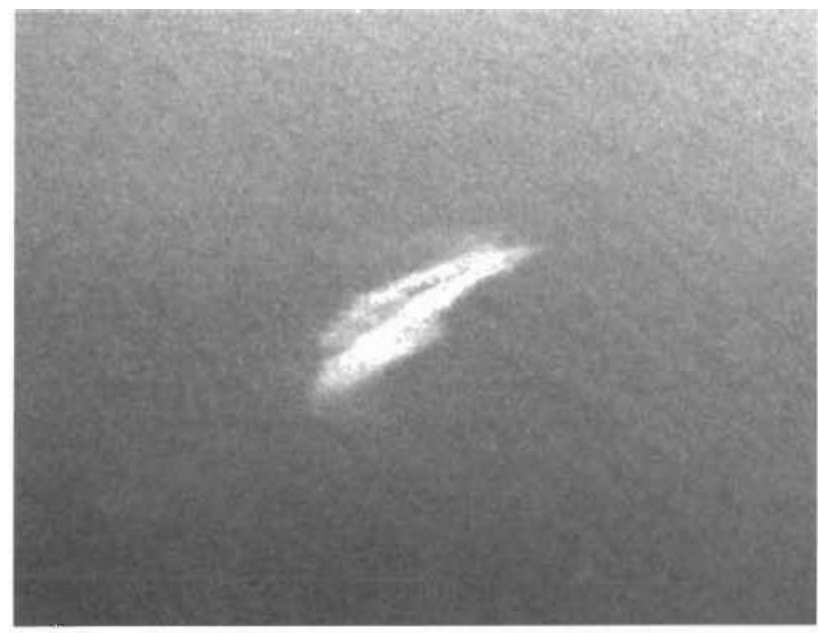

Fig. 3. Aurelia labiata. Aerial photograph of an aggregation of medusae in Prince William Sound in July 1996. The aggregation is approximately $20 \mathrm{~m}$ long by $6 \mathrm{~m}$ wide

of the tube $(F)$, and survey altitude $(A)$ are known, by using the equation $X=A\left({ }^{L} / F\right)$ (Lebida \& Whitmore 1985, Brady 1987). The average size categories of the aggregations are given in Table 1. Details of the aerial methodology are in Brown et al. (1999).

For comparisons of seasonal and interannual abundance, the total numbers and surface areas of aggregations were summed over each month and then divided by the total surface area flown during that

Table 1 Average size categories for jellyfish aggregations according to length $(L)$ and width $(W)$ using sighting tube during aerial surveys of Prince William Sound

\begin{tabular}{|lccc|}
\hline Category & $\begin{array}{c}L \times W \\
\text { (Tube units) }\end{array}$ & $\begin{array}{c}L \times W \\
\text { (m at } 308 \mathrm{~m} \text { altitude) }\end{array}$ & $\begin{array}{c}\text { Surface area } \\
\left(\mathrm{m}^{2} \text { at } 308 \mathrm{~m} \text { ) }\right.\end{array}$ \\
\hline Dab & $0.25 \times 0.10$ & $4.9 \times 2.0$ & 10 \\
Small & $0.50 \times 0.20$ & $9.7 \times 3.9$ & 38 \\
Medium & $1.00 \times 0.25$ & $19.5 \times 4.9$ & 96 \\
Large & $2.00 \times 0.50$ & $39.0 \times 9.7$ & 378 \\
\hline
\end{tabular}

month to obtain densities. Densities were expressed as numbers of aggregations or surface area $\left(\mathrm{m}^{2}\right)$ over the survey region $\left(\mathrm{km}^{2}\right)$.

Association of Aurelia labiata aggregations with age-0 walleye pollock. The PWS coastline was acoustically surveyed in July 1996. Four vessels were used during each $10 \mathrm{~d}$ survey $\left(12 \mathrm{~h} \mathrm{~d}^{-1}\right)$ : an acoustic vessel, a seiner, an oceanographic vessel, and a catch processing vessel. Surveys were conducted in daylight between 08:00 and 20:00 h.

The acoustic vessel followed a zig-zag pattern along the shore to a distance of $\sim 1 \mathrm{~km}$ at a speed of 14 to $17 \mathrm{~km} \mathrm{~h}^{-1}$. A Wesmar model $600 \mathrm{E}$ search light sonar was used to locate schools along the transect. When a school of fish was encountered, the acoustic vessel slowed to $9-11 \mathrm{~km} \mathrm{~h}^{-1}$ and completed a series of parallel transects perpendicular to the shore using a $120 \mathrm{kHz}$ BioSonics 101 echosounder with a preamplifier dual-beam transducer mounted $\sim 1$ m under the water surface (Stokesbury et al. 2000). The standard equation target strength $=20 \log x-66.0 \mathrm{~dB}$ was used to convert reflected acoustic energy into biomass (Foote \& Traynor 1988, MacLennan \& Simmonds 1992).

Echo integration measurements were made in roughly $20 \mathrm{~m}$ (16 pings cell ${ }^{-1}$ at 0.5 ping s $^{-1}$ and 2.5 to $3.0 \mathrm{~m} \mathrm{~s}^{-1}$ speed) horizontal by $1 \mathrm{~m}$ depth data cells during the July 1996 survey. Latitude and longitude were recorded simultaneously with each data cell from the GPS and provided an accurate measure of horizontal distance. Nonbiological noise, such as surface turbulence, was removed from these data. Species proportions and size modes per species were determined from the fish collections (described below). The echo integration measurements $\left(\mathrm{kg} \mathrm{m}^{-3}\right)$ were converted into numbers of individual fish per species by use of the species proportions, based on the number of individuals per fish species in the random subsample, and the length/weight regressions obtained in each seine catch. Based on frequency distributions of the data, we assumed that cells containing $<0.5$ fish $\mathrm{m}^{-3}$ were not aggregations of fish but probably zooplankton, therefore they were removed from the data set (MacLennan \& Simmonds 1992, Gunderson 1993). Fish located near the bottom were difficult to distinguish acoustically; if the signal appeared corrupted, the bottom $5 \mathrm{~m}$ were removed. Visual examination of the echograms and fish collections agreed with these assumptions.

Once the acoustic vessel surveyed a fish school, it was sampled to determine species composition and size structure. Fish were sampled using an anchovy seine $250 \mathrm{~m}$ long by $34 \mathrm{~m}$ deep with $25 \mathrm{~mm}$ stretch mesh. Each collection was separated into species and 1000 fish were randomly subsampled and measured for fork length (mm) and 450 for wet wt $(\mathrm{g}$ ) (Stokesbury et al. 2000). Jellyfish were also identified in the seine 
catches, and relative abundances of the different species estimated.

Behavior of jellyfish in the aggregations. In order to determine the swimming behavior of Aurelia labiata medusae in the aggregations, they were videotaped using a Hi-8 VCR and monitor attached to a closed-circuit underwater camera system (Fisheye, Inc., Everett, WA). The camera was lowered into the water when an aggregation was located, and the boat, moved mainly by the wind, was allowed to drift over the aggregation. The camera remained at constant depth. Ten aggregations were filmed in July 1996, 1997, and 1998 for a total of $80 \mathrm{~min}$ of video footage. All of the video footage was examined, and 2 aggregations were analyzed in detail with an editing Hi-8 VCR (Sony EV-S2000NTSC) and a Panasonic high resolution monitor.

Five types of information were evaluated for medusae in 2 aggregations. The video analysis was limited to 2 dimensions; therefore some inaccuracy is inherent in all of our measurements. (1) Relative densities of medusae from video images frozen at $10 \mathrm{~s}$ intervals were determined by counting the superposition of medusae on 42 arbitrary points marked on the video monitor. The number of points on medusae divided by the total number of points (42) gave an estimate of percentage cover for each image analysed, which we refer to as relative density. Actual densities of medusae could not be measured. (2) Angular swimming direction measurements were taken by marking the orientation of the oral-aboral axis relative to vertical on the video monitor and using a circular protractor to measure the swimming direction. $0^{\circ}$ was towards the water surface, and $90^{\circ}$ was towards the right. (3) Turning behavior was examined by following the paths of jellyfish for as long as each remained in view without contacting another jellyfish in low density areas, and after contact with other jellyfish in high density areas of an aggregation. No quantitative analysis of the swimming paths were attempted because of the lack of 3-dimensional resolution and short duration that individual medusae could be tracked. (4) Frequency of the swimming beat, which was used as an index of activity, was determined by counting the number of swimming bell contractions for as long as each medusa could be followed (<30 s). (5) The vertical distance moved relative to the body depth was used instead of actual displacement, which could not be determined. This index should not be affected much by medusa sizes, which were very similar for medusae (about 10 to $20 \mathrm{~cm}$ in diameter) within an aggregation. Relative distances (vertical distance moved $\div$ body depth at the oral-aboral axis) were measured from the video monitor for 1 full swimming beat cycle $(<3$ s), and standardized to $1 \mathrm{~s}$.

One-way analysis of variance (ANOVA) was used to compare swimming beat frequencies among 4 posi- tions within the aggregations: where medusae were swimming in 1 direction, either (1) up or (2) down, or in mixed orientations swimming (3) up or (4) down. If the ANOVA was significant overall among groups, then the Tukey test for multiple comparisons (Zar 1984) was used to test for differences among pairs of positions. The same statistical procedures were used to test for differences in relative densities, and relative distances moved per second among 3 groups: (1) up, (2) down, and (3) mixed

\section{RESULTS}

\section{Distribution and abundance of Aurelia labiata aggregations}

Aggregations of Aurelia labiata medusae were clearly visible during aerial surveys (Fig. 3). A total of 995 aggregations were observed during the 10 monthly surveys in PWS from 1995 to 1997. The majority $(81.2 \%)$ of the aggregations were categorized as small (approximately $40 \mathrm{~m}^{2}$ in surface area). The medium size category (approximately $100 \mathrm{~m}^{2}$ in surface area) made up most of the remaining total (14.7\%) (Fig. 4).

The abundance of aggregations followed a seasonal pattern (Fig 5). Aggregations were not observed during aerial surveys of PWS in March, April and May. Aggregations were first visible in June of 1996. Both numbers of aggregations and total surface areas per $\mathrm{km}^{2}$ of survey area peaked in August 1995 and July 1996; however, this trend was not observed in 1997. Between the months of July and August in 1995 and 1996, the abundance curve based on densities of surface areas departed from the abundance trends based

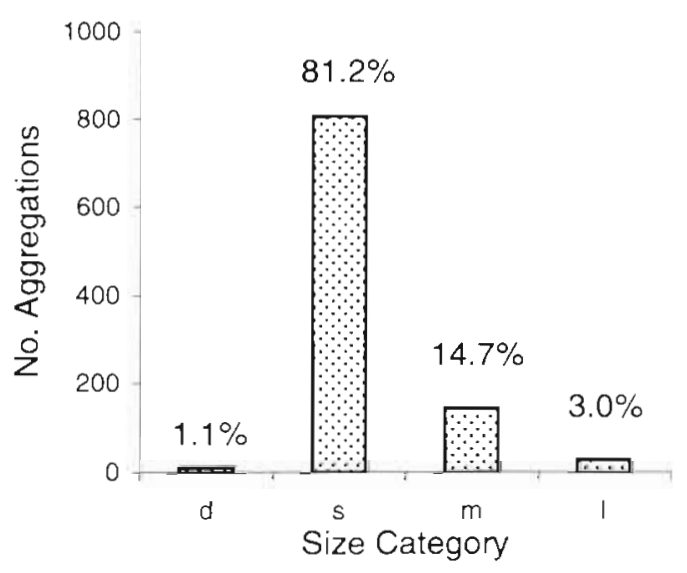

Fig. 4. Aurelia labiata. Size frequency distribution of aggregations in Prince William Sound in 1995, 1996, and 1997. $\mathrm{d}=\mathrm{dab}, \mathrm{s}=$ small, $\mathrm{m}=$ medium, $\mathrm{l}=$ large. Approximate sizes of each category are given in Table 1 The percentages of 995 aggregations in each category are given above each bar 


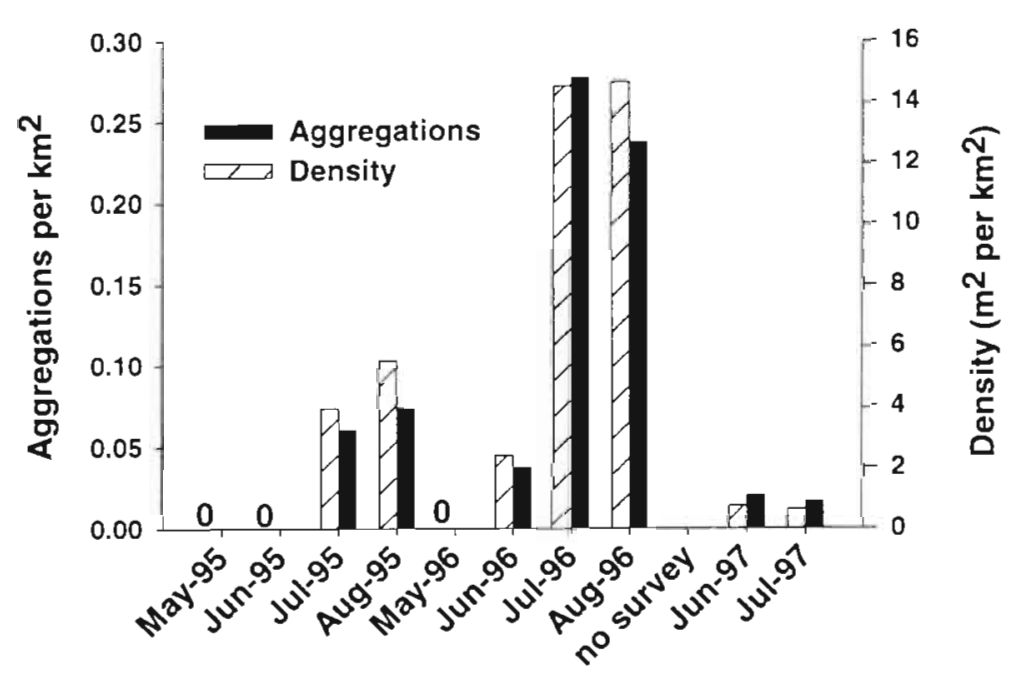

Fig. 5. Aurelia labiata. Seasonal and interannual variation in densities of jellyfish aggregations in Prince William Sound as estimated from aerial surveys in 1995, 1996, and 1997. Data presented as the numbers of aggregations per $\mathrm{km}^{2}$ and as surface areas of aggregations per $\mathrm{km}^{2}$
PWS that were surveyed by air (Unakwik Inlet, Port Valdez, and Valdez Arm) (Fig. 6).

\section{Association of Aurelia labiata aggregations with age-0 walleye pollock}

Schools of young-of-the-year (age-0) walleye pollock were observed on videotapes and acoustically under and within aggregations of Aurelia labiata medusae. The juvenile fish were observed associated with 2 (in Paddy Bay and Port Gravina in July 1996) of the 10 videotaped aggregations. In Simpson and Drier Bays, where acoustic transects were completed through jellyfish aggregations, $A$. labiata appeared to extend from the water's surface to the beginning of the thermocline at about 10 to $20 \mathrm{~m}$ depth. Mean densities of age-0 walleye pollock schools observed in Simpson and Drier Bays were 13.9 and 35.0 fish $\mathrm{m}^{-3}$, respectively (Table 3 ).

Seine catches along the transects in Simpson and Drier Bays confirmed that the acoustic targets were predominately age-0 walleye pollock. The largest catches of juvenile walleye pollock from 52 seine sets in July 1996 in PWS were from Simpson Bay (394 fish) and Drier Bay (7000 fish). Sizes of the fish (mean fork length $<61 \mathrm{~mm}$ ) showed them to be young-of-the-year. Age- 0 walleye pollock were the second most abundant fish collected during this survey in PWS (Stokesbury et al. 2000).

\section{with 2-fold greater densities in 1996 than 1995, and} generally low densities for 1997 (Figs. 5 \& 6). Significantly more aggregations and greater surface areas were found in 15 inlets of PWS (Table 2) in 1996 than in 1995 ( $\mathrm{p}<0.01$ ) or in 1997 ( $\mathrm{p}<0.001$; Wilcoxin signed-rank tests).

Most aggregations were observed in bays off the main sound (Fig. 6), possibly due to the concentration of survey effort there (Fig, 1). Aggregations were observed consistently in 15 bays during 1 or more surveys in every year. The aggregations were most widely distributed in 1996 (15 of 15 bays plus other sites not occupied in other years), as compared with 9 of 15 bays plus other sites in 1995 and 5 of 15 bays in 1997 (Table 2). Bays in southwestern PWS (Whale, Drier, and Jackpot Bays) and in northeastern PWS (Port Fidalgo, Port Gravina, Simpson Bay) had the highest numbers and surface areas of aggregations in 1995 and 1996. Ewan Bay and Port Fidalgo were the only locations that had aggregations every year. Also striking was the lack of aggregations in the large inlets of northern

Table 2. Aurelia aurita. Numbers of aggregations and their combined surface areas in Prince William Sound in bays where they most frequently occurred. Data are presented for the survey in each year having the greatest number of aggregations. The bays are listed from southwest PWS clockwise around the coastline

\begin{tabular}{|c|c|c|c|c|c|c|}
\hline \multirow{2}{*}{$\begin{array}{l}\text { Location } \\
\text { Whale Bay }\end{array}$} & \multicolumn{2}{|c|}{$\begin{array}{l}5-22 \text { Aug } 1995 \\
\text { No. Area }\left(\mathrm{m}^{2}\right)\end{array}$} & \multicolumn{2}{|c|}{$\begin{array}{l}2-21 \text { Jul } 1996 \\
\text { No. Area }\left(\mathrm{m}^{2}\right)\end{array}$} & \multicolumn{2}{|c|}{$\begin{array}{l}\text { 12-21 Jun } 199 \\
\text { No. Area }\left(\mathrm{m}^{2}\right.\end{array}$} \\
\hline & 7 & 498 & 17 & 646 & 0 & 0 \\
\hline Drier Bay & 8 & 478 & 145 & 8544 & 0 & 0 \\
\hline Jackpot Bay & 18 & 916 & 68 & 3222 & 0 & 0 \\
\hline Ewan Bay & 3 & 172 & 7 & 324 & 2 & 20 \\
\hline Paddy Bay & 0 & 0 & 7 & 266 & 5 & 200 \\
\hline Naked Island & 0 & 0 & 7 & 266 & 0 & 0 \\
\hline Eaglek Bay & 0 & 0 & 81 & 3460 & 18 & 602 \\
\hline Wells Bay & 0 & 0 & 54 & 2052 & 0 & 0 \\
\hline Jack Bay & 0 & 0 & 4 & 152 & 0 & 0 \\
\hline Galena Bay & 0 & 0 & 45 & 2206 & 2 & 48 \\
\hline Port Fidalgo & 28 & 2034 & 17 & 2122 & 1 & 38 \\
\hline Port Gravina & 16 & 898 & 22 & 1864 & 0 & 0 \\
\hline Orca Bay & 3 & 173 & 4 & 550 & 0 & 0 \\
\hline Sheep Bay & 1 & 378 & 3 & 144 & 0 & 0 \\
\hline Simpson Bay & 10 & 380 & 12 & 688 & 0 & 0 \\
\hline
\end{tabular}



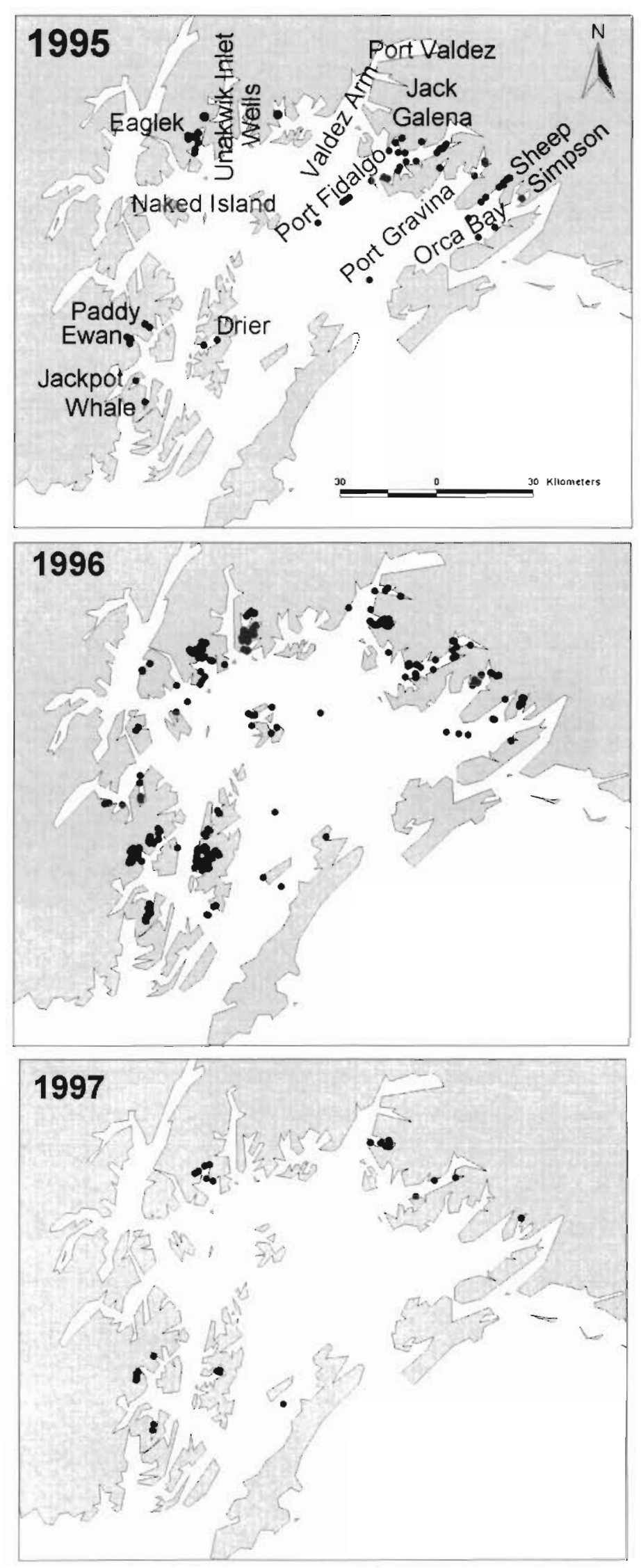

Aurelia labiata was the only large medusa collected in the seine catch in Simpson Bay. Some Aequorea aequorea var, albida and Cyanea capillata medusae also occurred in the seine catch from Drier Bay. The jellyfish catches in Drier and Simpson Bays were much greater than in 49 of the other 50 seine sets in other locations.

In all seine sets in which they were collected $(27 \%)$, age-0 walleye pollock were collected with jellyfish; they did not occur alone or with herring only (Table 4). By contrast, herring often occurred alone $(27 \%)$ in the seine catches. Jellyfish, age-0 walleye pollock, and herring occurred together in 4 of 52 seine samples. Although age- 0 walleye pollock were only collected with jellyfish, herring were as likely to be collected alone as with jellyfish. The difference between the 2 fish species occurring with and without jellyfish was significant (chi-square $=7.9, p=0.005$ ). Jellyfish occurred alone in $25 \%$ of the seine samples.

\section{Behavior of jellyfish in the aggregations}

Aurelia labiata medusae were observed on videotapes of 10 aggregations (Fig. 7). Two aggregations were studied in detail where camera motion was minimal in light wind conditions. A video transect through Aggregation 1 was taken at $4.3 \mathrm{~m}$ depth on 18 July 1998 at 17:00 h along the southwestern part of Chenega Island $\left(60^{\circ} 19.55^{\prime} \mathrm{N}, 148^{\circ} 9.20^{\prime} \mathrm{W}\right)$, where bottom depth was $21.5 \mathrm{~m}$. Aggregation 2, which extended from the surface to $12.3 \mathrm{~m}$, was videotaped at $4.6 \mathrm{~m}$ at 08:00 h on 29 July 1998 in Jackpot Bay $\left(60^{\circ} 20.22^{\prime} \mathrm{N}, 148^{\circ} 16.17^{\prime} \mathrm{W}\right)$. The following results for Aggregations 1 and 2 were representative of those for other aggregations, for which some supporting data are also given.

A 3 min horizontal transect through Aggregation 1 showed 3 areas: 1 side where medusae were swimming downwards in high $(46 \%)$ relative density, a central area where medusae were in mixed orientations and low (7\%) relative density, and the opposite side where medusae were

Fig. 6. Aurelia labiata. Distributions of aggregations of medusae in Prince William Sound during broadscale aerial surveys in July, 1995, 1996, and 1997. Many points overlap in 1995 and 1996, especially in certain bays (e.g. Drier Bay, Jackpot Bay, Port Fidalgo and Port Gravina). Table 2 gives the actual numbers of aggregations in the bays for the survey having the most aggregations in each year 
Table 3. Aurelia aurita and Theragra chalcogramma. Characteristics of acoustic transects in Simpson and Drier Bay in Prince William Sound. Depths of jellyfish aggregations and densities and depths of walleye pollock were determined by acoustics. Percentages of the catch and size (fork length) of walleye pollock were determined from seine catches. Numbers represent means \pm 1 standard deviation

\begin{tabular}{|lcc|}
\hline & Simpson Bay & Drier Bay \\
\hline Date & 2 Jul 1996 & $8 \mathrm{Jul} 1996$ \\
Latitude and longitude & $60.676^{\circ} \mathrm{N}, 145.858^{\circ} \mathrm{W}$ & $60.320^{\circ} \mathrm{N}, 147.775^{\circ} \mathrm{W}$ \\
Bottom depth (m) & $26.8 \pm 13.6$ & $39.5 \pm 3.2$ \\
A. aurita (\% of seine catch) & $99 \%$ & $97 \%$ \\
Depth $(\mathrm{m})$ & $0-10$ & $0-20$ \\
$T$ chalcogramma (no. $\left.\mathrm{m}^{-3}\right)$ & $13.9 \pm 28.3$ & $35.9 \pm 76.8,34.4 \pm 59.7$ \\
$\%$ of seine catch & $1 \%$ & $3 \%$ \\
Mean depth $(\mathrm{m})$ & $12.8 \pm 7.6$ & $16.1 \pm 11.6$ \\
Size $(\mathrm{mm})$ & $49.9 \pm 6.3$ & $60.8 \pm 4.6$ \\
\hline
\end{tabular}

dusae, in response to some unknown stimulus or after contact with one another, would lead to increased densities. The first null hypothesis we tested was that medusae swam in random directions, which could indicate frequent turning.

All medusae were swimming, and most were oriented vertically (Table 5 , Figs. $7 \& 8$ ). Of the several thousands of medusae videotaped in 10 aggregations, only 29 medusae were observed turning without contact with other medusae (24 turned from horizontal to downward swimming, and 5 from horizontal to upward swimming). If turning were the mechanism for aggregation,

swimming upwards in high (22\%) relative density (Fig. 8). In Aggregation 2, a dense central column of upward-swimming medusae spread horizontally near the surface (96\% relative density), where medusae in this sub-surface canopy swam upwards while repeatedly contacting one another. On the lower and outer edges of the horizontal canopy of the aggregation ( $91 \%$ relative density), some medusae were observed turning from upward to downward orientation, moving into areas of lower $(25 \%)$ relative density and generally downward swimming. Eight other aggregations had a dense central core oriented either vertically or in a horizontal or tilted layer, with medusae generally swimming upwards on both sides of the dense layer.

In all aggregations, there were areas of high and low medusa densities (Tables $5 \& 6$ ). The relative densities were significantly different among areas within the aggregations; for Aggregation 1: ANOVA: $\mathrm{df}=2,27$, $F=160.67, \mathrm{p}<1 \times 10^{-14}$, and for Aggregation 2: ANOVA, $\mathrm{df}=2,16, F=87.67, \mathrm{p}=1.27 \times 10^{-10}$. The following hypotheses were tested comparing medusae among low and high density areas.

The first of 3 possible explanations for aggregation of Aurelia labiata was that increased turning by me-

Table 4. Aurelia aurita, Theragra chalcogramma, and Clupea pallasi. Matrix of occurrence in 52 seine catches in Prince William Sound on 2 to 11 July 1996. Seine sets were made on fish schools located acoustically. Catches having just jellyfish are at the intersection of the jellytish row and column. Only 4 catches contained jellyfish, walleye pollock, and herring, and these are not included in any column.

\begin{tabular}{lccc|} 
& Jellyfish & Pollock & Herring \\
\hline Jellyfish & 13 & 10 & 11 \\
Pollock & - & 0 & 0 \\
Herring & - & - & 14 \\
\hline
\end{tabular}
we would expect to see a higher proportion of non-vertical medusae in the most crowded parts of the aggregations. In Aggregation 1, the opposite was observed; medusae at low densities showed greater deviations from vertical swimming (Fig. 8). The up-to-downward turning observed at the periphery of Aggregation 2 took medusae away from the most crowded parts of the aggregation. We reject the first null hypothesis; medusa swimming was mostly vertical. Increased turning was not observed where medusae were in high densities.

The second possible explanation for aggregation formation was that if medusae swam persistently in 1 direction, they would be retained in features like Langmuir circulation cells (Stavn 1971). Therefore, we would expect that medusae oriented in 1 direction would be in high densities. The second null hypothesis we tested was that medusae would occur in equal densities, regardless of swimming orientation.

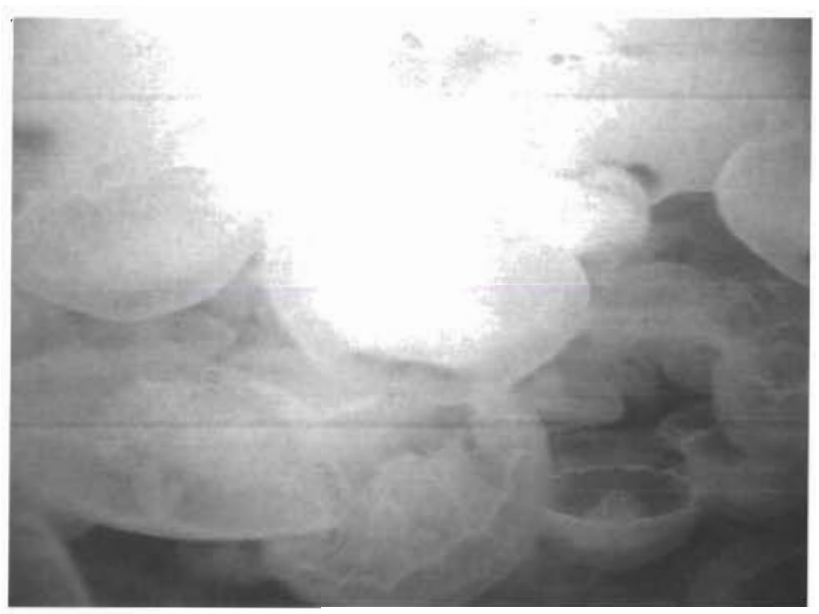

Fig. 7. Aurelia labiata. Underwater videotape image from a jellyfish aggregation. The medusae $(\sim 15 \mathrm{~cm}$ in diameter) are swimming directly away from the surface 


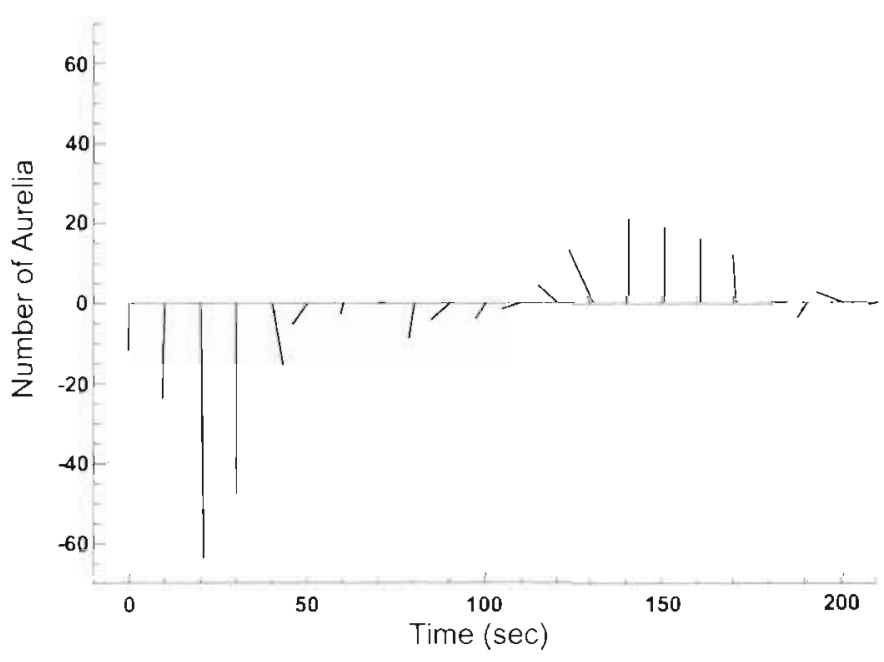

Fig. 8. Aurelia labiata. Vector diagram of mean medusa swimming direction (angle of the sticks), and abundance (length of the sticks) during a $3 \mathrm{~min}$ videotape transect at $4.3 \mathrm{~m}$ depth through a jellyfish aggregation. Sticks above the horizontal axis represent swimming upwards, with straight up $\left(0^{\circ}\right)$ being vertical swimming up. Sticks below the axis represent swimming downwards, with straight down $\left(180^{\circ}\right)$ being vertical swimming down. The lengths of the sticks represent the numbers of medusae at each $10 \mathrm{~s}$ interval. The videotape frames were 'frozen' at 10 s intervals, and swimming direction determined for all medusae in that image

Medusae that were swimming directionally were in high densities in all 10 aggregations. Evidence from Aggregations 1 and 2 showed that medusae swimming unidirectionally had higher densities than those swimming in mixed orientations, and the differences were significant (Tables $5 \& 6$ ). In Aggregation 1, the prevailing orientation of medusae changed from all swimming downward to all swimming upward during a span of only $100 \mathrm{~s}$ on the videotape (Fig. 8). We reject the second null hypothesis; medusae swimming vertically had higher densities than medusae in mixed orientations.

A third possible explanation for aggregation was that swimming was reduced where medusae were crowded, relative to uncrowded areas. The third null hypothesis, that medusae swam similarly regardless of the degree of crowding, was tested by using 2 indicators of swimming - swimming beat frequency and vertical distance moved.

Medusae in aggregations where individual medusae could be followed for only 2 to $3 \mathrm{~s}$ (1 full swimming beat) did not show differences in swimming beat frequencies depending on density or orientation. For example, medusae in Aggregation 1 showed very similar rates for upward- and downward-swimming medusae at high and low relative densities (ANOVA, $\mathrm{df}=3,29, F=1.10, \mathrm{p}=0.36$; Tables $5 \& 6)$. The beat frequencies of upward- (mean 0.43 beats $\mathrm{s}^{-1}, \mathrm{n}=20$ ) and downward- (mean 0.41 beats $\mathrm{s}^{-1}, \mathrm{n}=15$ ) swimming medusae were compared from the low density areas of 3 additional aggregations and found not to be significantly different (ANOVA, $\mathrm{df}=2,32, F=0.51$, $\mathrm{p}=0.48$ ). Medusae in the high density areas of those aggregations could not be tracked long enough to determine the beat frequencies

By contrast, swimming beat frequencies were significantly different in different areas of Aggregation 2, where individual medusae could be followed for up to $25 \mathrm{~s}$ (ANOVA, df $=3,51, F=29.59, \mathrm{p}=3.6 \times 10^{-10}$ ). In areas of high relative densities, uniformly upwardswimming medusae had significantly different beat frequencies $\left(0.57\right.$ beats $\left.\mathrm{s}^{-1}\right)$ than downward-swimming medusae $\left(0.36\right.$ beats $\left.\mathrm{s}^{-1}\right)$, which had just reversed swimming direction at the bottom of the crowded canopy of the aggregation (Tables $5 \& 6$ ). The lower

Table 5. Aurelia aurita. Medusa swimming beat frequencies, relative vertical distance moved per second, and relative densities for areas in aggregations where medusae swam unidirectionally up, unidirectionally down, or where medusae were in mixed orientations, as analysed from videotapes. Numbers are means \pm 1 standard deviation. The numbers of measurements are in parentheses, which for swim beats and relative distances are the number of medusae, and for relative densities are the numbers of video frames. Relative distance (distance $\div$ body depth) is a measure of the vertical displacement during 1 swimming beat (standardized to $1 \mathrm{~s}$ ), because actual distances could not be determined. Relative density is a measure of the percentage of the video image covered by jellyfish, and is used to compare the abundances of jellyfish because absolute density could not be determined

\begin{tabular}{|c|c|c|c|c|}
\hline \multirow{2}{*}{ Variable } & \multicolumn{4}{|c|}{ Location in aggregation } \\
\hline & Up & Down & Mixed up & Mixed down \\
\hline \multicolumn{5}{|c|}{ Swim beat (no. s $^{-1}$ ) } \\
\hline Aggregation 1 & $0.51 \pm 0.30(7)$ & $0.51 \pm 0.09(12)$ & $0.51 \pm 0.05(5)$ & $0.57 \pm 0.09(9)$ \\
\hline Aggregation 2 & $0.57 \pm 0.11(18)$ & $0.36 \pm 0.06(16)$ & $0.59 \pm 0.10(11)$ & $0.67 \pm 0.13(9)$ \\
\hline \multicolumn{5}{|c|}{ Relative distance $\left(\mathrm{s}^{-1}\right)$} \\
\hline Aggregation 2 & $0.36 \pm 0.32(13)$ & $0.41 \pm 0.20\{12\}$ & $1.04 \pm 0.65(11)$ & $0.30 \pm 0.34(10)$ \\
\hline \multicolumn{5}{|c|}{ Relative density $(\%)$} \\
\hline Aggregation 1 & $22 \pm 5(10)$ & $46 \pm 11(10)$ & \multicolumn{2}{|c|}{$7 \pm 15(10)$} \\
\hline Aggregation 2 & $96 \pm 5(5)$ & $91 \pm 13(9)$ & \multicolumn{2}{|c|}{$25 \pm 11(5)$} \\
\hline
\end{tabular}


Table 6. Aurelia aurita. Probability values ( $p$ ) for statistical tests (the Tukey test for multiple comparisons) comparing swim beat frequencies and relative densities among areas within aggregations where medusae swam unidirectionally up or unidirectionally down, or where medusae were in mixed orientations. Swim beat freqencies were not significantly different overall for Aggregation 1, but were for Aggregation 2 (ANOVAs, see text). The relative densities were significantly different overall among areas (ANOVA, see text $) . n s=$ not significant,$p>0.05$

\begin{tabular}{|lcc|}
\hline Orientation & Aggreg. 1 & Aggreg. 2 \\
\hline Swim beats (no. $\mathbf{~ s}^{-1}$ ) & & \\
Up vs down & ns & 0.001 \\
Up vs mixed up & ns & ns \\
Up vs mixed down & ns & 0.05 \\
Down vs mixed up & ns & 0.001 \\
Down vs mixed down & ns & 0.001 \\
Mixed down vs mixed up & ns & ns \\
Relative density (\%) & & \\
Up vs down & 0.001 & ns \\
Up vs mixed & 0.001 & 0.001 \\
Down vs mixed & 0.001 & 0.001 \\
\hline
\end{tabular}

swimming beat frequency of the downward-turning medusae could slow their movement away from the dense aggregation. In areas of low density where medusae were oriented in mixed directions, the beat frequencies of upward-and downward-swimming medusae were not significantly different, and upwardswimming medusae also had similar beat frequencies in both high and low density areas (Tables 5 \& 6).

We tested whether the vertical distance moved relative to body depth differed between crowded and uncrowded areas of Aggregation 2. There was a significant difference in relative distance moved per second among the different areas of the aggregation (ANOVA, df $=3,42, F=8.02, p=2.44 \times 10^{-4}$ ). Medusae swimming up in uncrowded areas moved further (1.04 $\left.\mathrm{s}^{-1}\right)$ than medusae swimming up in crowded areas or down in either low or high densities 0.30 to $0.41 \mathrm{~s}^{-1}$ ), and the differences were significant (Tables 5 \& 6). Comparisons among all other pairs (downwardswimming medusae in high densities, in low densities, and upward-swimming medusae in high densities) were not significantly different (Tables $5 \& 6$ ). The smaller vertical distance traveled by crowded medusae would concentrate them relative to those swimming freely. We rejected the third null hypothesis; medusae oriented downward in high densities had reduced swim beat frequencies, and those oriented upward in high densities were impeded in vertical motion by collisions with other medusae.

In summary, we observed 3 factors that could act to concentrate Aurelia labiata medusae. First, the persistent vertical swimming observed would concentrate medusae in flow fields in the water column, such as convergences. Second, downward-swimming medusae leaving crowded areas had lower swimming beat frequencies and relative vertical distances moved than all other medusae. And third, medusae in crowded parts of aggregations were unable to move as far as medusae in low density areas due to collisions with other medusae.

\section{DISCUSSION}

\section{Distribution and abundance of Aurelia labiata aggregations}

Marked interannual differences were seen in the numbers of Aurelia labiata aggregations in PWS, with 1996 having by far the greatest number. The summer of 1996 also showed high densities of hydromedusae in PWS (K. O. Coyle, R. T. Cooney, and M. V. Sturdevant unpubl. data). That year was characterized by deep mixing (Vaughan et al, pers. comm.), and high zooplankton densities (Sturdevant 1999). By contrast, 1997 was an unusually warm year (Haldorson et al. 1998), reflecting atmospheric effects of the strong El Niño that developed in the southern hemisphere. In 1997 there were also low densities of hydromedusae and zooplankton (J.E.P. unpubl. data).

Aurelia labiata aggregations were observed in nearly every small bay and inlet of PWS; however, they were noticeably absent in large inlets in the north (Unakwik Inlet, Valdez Arm and Port Valdez). These large, northern inlets have glaciers and surface layers are opaque with glacial till, which may have reduced visibility of the aggregations during the aerial surveys. Those inlets also have very steep topography, which may not promote vertical water fluxes at the depths (Simpson 1974) needed for aggregation formation.

Toyokawa et al. (1997) reported that Aurelia aurita aggregations drifted with the tidal currents; however Hamner et al. (1994) stated that the aggregations maintained their position along the eastern shoreline of Saanich Inlet and did not move with the tides. Our sampling did not allow us to observe whether or not the aggregations drifted with the tides.

\section{Association of Aurelia labiata aggregations with age-0 walleye pollock}

Associations between juvenile walleye pollock and individual Cyanea capillata and Chrysaora melanaster have been described previously (summarized in Brodeur 1998). Schools of age-0 walleye pollock were documented by underwater video in association with 
2 aggregations of Aurelia labiata. To our knowledge, the association of fish schools with jellyfish aggregations has not been reported previously. Acoustic records and seine catches in Simpson and Drier Bays in July 1996, when $A$. labiata aggregations were very abundant, suggest that age-0 walleye pollock were associated primarily with the aggregations; throughout an intense $10 \mathrm{~d}$ broadscale survey of the nearshore ichthyofauna, the pollock were collected with only $A$. la biata jellyfish. By contrast, in July 1999, when A. labiata aggregations were virtually absent in PWS, video observations showed age-0 walleye pollock schooling alone near bottom, and also in association with solitary Cyanea capillata medusae (J.E.P. pers. obs.).

Commensal relationships among fish and jellyfish are believed to protect the juvenile fish from their many vertebrate predators (e.g. Brodeur 1998) and possibly provide food, either as prey stolen from the jellyfish or the jellyfish themselves. Juvenile butterfish Peprilus triacanthus are eaten by birds when displaced from their jellyfish hosts, Cyanea capillata medusae (Duffy 1988), and are known to eat parts of the jellyfish (Mansueti 1963). Juvenile walleye pollock are eaten by a variety of fish, sea birds, and pinnepeds (summarized in Okey \& Pauly 1998). For example, age-0 walleye pollock made up $19 \%$ of the diet of tufted puffins Fratercula cirrhata, which consumed an estimated 11 billion individuals along the Gulf of Alaska in 1986 (Hatch \& Sanger 1992). Perhaps the association of age-0 walleye pollock with jellyfish reduces their capture by vertebrate predators.

Acoustic detection of gelatinous species is not widely known. Acoustics are most effective when used to survey fishes with gas bladders (MacLennan \& Simmonds 1991). The large difference in density between gas bladders and the water surrounding the fish yields strong acoustic signal strength, but bone, liver and fatty tissues produce a much weaker signal (MacLennan \& Simmonds 1991). The density of fish flesh is so nearly equal to that of seawater that the animal is virtually transparent to sound (Lagler et al. 1977), and this would be expected for jellyfish as well, which have high water contents and salt compositions similar to seawater (e.g. Clarke et al. 1992). Nevertheless, jellyfish aggregations have been studied using acoustic techniques previously (Toyokawa et al. 1997). The acoustic equipment used during our survey and on subsequent cruises appeared to detect aggregations of Aurelia labiata; however, schools of age-0 walleye pollock were associated with them, which would have enhanced the acoustic signal strength. Solitary Cyanea capillata medusae were detected acoustically in July 1999, and each medusa was observed by underwater video to have several associated juvenile gadids, some of which could be identified as walleye pollock (J.E.P. pers. obs.). Also in July 1999, the gut contents of large Aequorea aequorea var. albida medusae had partly digested juvenile gadids (J.E.P. pers. obs.), probably walleye pollock, which could enhance an acoustic signal. Seine sets on acoustic targets thought to be fish schools sometimes yielded large catches of $A$. aequorea instead of fish (J.E.P. pers. obs.). Therefore, the acoustic signals apparently reflecting from jellyfish may reflect off, at least in part, juvenile fish near or in them.

\section{Behavior of jellyfish in the aggregations}

Few data exist on the behavior of Aurelia spp. medusae in situ. Our observations on the swimming of A. labiata medusae in aggregations concur with data on solitary medusae from Costello et al. (1998), specifically, that individuals swim all the time and that most swimming is vertical. Our observations differed somewhat from those of Hamner et al. (1994), who described the formation of medusa aggregations in Saanich Inlet $\left(49^{\circ} \mathrm{N}\right)$, a fjord on Vancouver Island, where the jellyfish swam horizontally towards the southeast in sunlight. When the medusae reached an aggregation, their directed horizontal swimming changed to vertical. The medusae did not show horizontal swimming before sunrise, when the sky was overcast, or at night. We did not observe horizontal directional swimming by medusae in PWS, and aggregations existed during both clear and overcast days. Jellyfish in PWS $\left(60.5^{\circ} \mathrm{N}\right)$ experienced from $19 \mathrm{~h}$ of daylight in mid-June, decreasing to $15.5 \mathrm{~h}$ in mid-August. All of our sampling was in daylight, and we do not know if the aggregations dispersed during the short nights in PWS, or how long each aggregation persisted.

Behavioral mechanisms, in combination with physical features in the water column, are probably responsible for the formation and maintenance of Aurelia spp. aggregations. We eliminated one potential mechanism of aggregation; the medusae swam in straight paths and therefore did not maintain the aggregations by swimming in circles, as seen for Linuche unguiculata (Larson 1992), or increased rates of turning (klinokinesis) as used for swarm formation in copepods (Buskey et al. 1996). Again, our results are in contrast with those of Hamner et al. (1994), who reported 'constant collision and turning' by medusae in high density aggregations. We observed a variety of swimming orientations of medusae in low density, possibly reflecting non-vertical swimming, which might help them encounter convergences in the water column and already aggregated medusae.

The second explanation for aggregation was that medusae swam directionally, which would retain them 
in features like Langmuir circulation cells (Stavn 1971). Swimming by Aurelia labiata in crowcled parts of all aggregations was oriented vertically. The fact that jellyfish in one part of Aggregation 1 all swam upwards while all nearby individuals swam down, suggests that medusae in this aggregation were swimming in a convection cell. This is supported by Toyokawa et al. (1997), who described 'ring-like' structure of some A. aurita aggregations. In other locations, swimming jellyfish, including Aurelia spp., have been seen concentrated in convergences between Langmuir cells, which are wind-driven, surface convection cells that form perpendicular to the wind direction (Hamner \& Schneider 1986, Larson 1992), and in fronts (Shanks \& Graham 1987, Graham 1994)

Convection currents in PWS are probably from multiple origins, including wind-driven Langmuir cells that form in the inlets (S. M. Gay pers. comm.). Also, the kinetic energy of high-speed currents is converted to strong vertical water flows by friction over shallow bottom topography (Mackas et al. 1985). The large tides (about $8 \mathrm{~m}$ amplitude) in the narrow fjords of PWS may frequently create regions of strong shear in the water column. The highly directional upward and downward swimming by medusae observed in high density areas of all aggregations suggests that the medusae were retained in flow fields in the water column. Unfortunately, we lacked concurrent data on water flow.

A few species of jellyfish, including Aurelia spp., Chrysaora fuscescens, and Stomolophus meleagris, have been observed swimming against the prevailing water flow in situ and in aquaria (Hamner \& Schneider 1986, Shanks \& Graham 1987, J.E.P. \& W. M. Graham pers, obs.). The swimming currents generated ('bioconvection') by the medusae in the aggregations may promote persistence of the aggregations, as for microorganisms (Kils 1993). The mechanism by which medusae orient to flow is not known. Aurelia spp. control their orientation by use of ocelli, which sense light, and statocysts, which sense gravity, at 8 evenly spaced locations around the swimming bell margin (Arai 1997). Possibly, asymmetric deformation of the swimming bell may signal medusae to orient into water flow.

The third possible explanation for aggregation was that reduced swimming, which acted to concentrate Daphnia in high food concentrations (Larsson \& Kleiven 1996), may act to concentrate Aurelia spp. medusae. The medusae in dense aggregations did not have reduced swimming beat frequencies; however, crowded medusae could not move as far as those in low densities due to frequent collisions with other medusae. Also, medusae swimming downward after leaving dense aggregations had reduced swimming beat frequencies. Therefore, this mechanism could act to concentrate medusae.

Although chemoreception has been demonstrated in jellyfish, we do not know if chemical cues attract medusae to aggregate. Chemoreception that facilitates intraspecific interactions (other than sperm attraction) has not been investigated for any gelatinous zooplankton, to our knowledge. Chemoreception by jellyfish has been demonstrated to exudate from a jellyfish predator (Lenhoff 1964) and from prey (Arai 1992, Falkenhaug et al. 1995, Purcell \& Anderson 1995). This suggests that gelatinous species may use distance chemoreception in a variety of ways, which could include aggregation.

Aurelia spp. medusae may gain several advantages from aggregation. First, Hamner et al. (1994) found that about $5 \%$ of male medusae were releasing sperm in aggregations, and concluded that the aggregations function to increase fertilization success. Second, retention near shore would be advantageous because Aurelia spp. medusae release planulae that settle on hard substrata (e.g. Hernroth \& Grondahl 1985). Vertical swimming is displayed by a variety of estuarine meroplankton, which serves to retain them in the estuaries where these larvae must settle (e.g. Wooldridge \& Erasmus 1980, Tankersley et al. 1995). Third, there may be advantages of aggregation for feeding. Plankton abundances are greater near shore than off shore in PWS (Cooney \& Coyle 1997), and plankton organisms are concentrated in convergences and fronts (e.g. Graham 1994), so medusae would aggregate where food densities are greatest. Fourth, schooling by other animals is a well-documented defense against predators (e.g. Hamner 1996), and may be effective for jellyfish as well. Phacellophora camtschatica and Cyanea capillata scyphomedusae feed on Aurelia spp. medusae (Strand \& Hamner 1988, Båmstedt et al. 1994, Hansson 1997). Abundant C. capillata consumed A. labiata along the diffuse edges of aggregations in PWS; however, one C. capillata medusa within a dense aggregation was continually impacted by the swimming A. labiata medusae and was unable to swim or feed (J.E.P. pers. obs.). Thus, the potential advantages of aggregation are numerous.

Acknowledgements. This research was funded by the 'Exxon Valdez' Oil Spill Trustee Council as part of the Alaska Predator Ecosystem eXperiment (APEX Projects 96163A, 97163A, 98163A, and 99163S) and as part of the Sound Ecosystem Assessment (SEA Projects 95320T, 96320T, and 97320T). We thank Carole Derry for preparing the vector diagram (Fig. 8), and $\mathrm{M}$. Leonard and $\mathrm{M}$. B. Decker for assisting with other figures. We are very grateful to Drs K. A Coyle, R. T. Cooney, S. L. Vaughan, M. V. Sturdevant and S.M. Gay, who have provided data, unpublished manuscripts, and insights to the physics and biology of PWS. UMCES Contribution No. 3236. 


\section{LITERATURE CITED}

Arai MN (1988) Interactions of fish and pelagic coelenterates Can J Zool 66:1913-1927

Arai MN (1992) Attraction of Aurelia and Aequorea to prey. Hydrobiologia 216/217:363-366

Arai MN (1997) A functional biology of Scyphozoa. Chapman \& Hall, London

Ates RML (1988) Medusivorous fishes, a review. Zool Meded 62: $29-42$

Båmstedt U (1990) Trophodynamics of scyphomedusae Aurelia aurita. Predation rate in relation to abundance, size and type of prey organism. J Plankton Res 12:215-229

Båmstedt U, Martinussen MB, Matsakis S (1994) Trophodynamics of the two scyphozoan jellyfishes, Aurelia aurita and Cyanea capillata, in western Norway. ICES J Mar Sci 51:369-382

Behrends G, Schneider G (1995) Impact of Aurelia aurita medusae (Cnidaria, Scyphozoa) on the standing stock and community composition of mesozooplankton in the Kiel Bight (western Baltic Sea). Mar Ecol Prog Ser 127:39-45

Brady JA (1987) Distribution, timing, relative biomass indices for Pacific herring as determined by aerial surveys in Prince William Sound 1978-1987. Prince William Sound Data Report No. 87-14. Alaska Department of Fish and Game, Division of Commercial Fisheries, Juneau, AK

Brodeur RD (1998) In situ observations of the association between juvenile fishes and scyphomedusae in the Bering Sea. Mar Ecol Prog Ser 163:11-20

Brown ED, Moreland SM, Norcross BL, Borstad GA (1999) Estimating forage fish and seabird distribution and abundance using aerial surveys: survey design and uncertainty. In: Cooney RT (ed) Sound Ecosystem Assessment (SEA) - an integrated science plan for the restoration of injured species in Prince William Sound. Exxon Valdez Oil Spill Restoration Project Final Report (Restoration Project 99320T), Anchorage, AK, p 131-172

Buskey EJ, Peterson JO, Ambler JW (1996) The role of photoreception in the swarming behavior of the copepod Dioithona oculata. In: Lenz PH, Hartline DK, Purcell JE, Macmillan DL (eds) Zooplankton: sensory ecology and physiology. Gordon and Breach Publ, Amsterdam, p 301-313

Clarke A, Holmes LJ, Gore DJ (1992) Proximate and elemental composition of gelatinous zooplankton from the Southern Ocean. J Exp Mar Biol Ecol 155:55-68

Clausen DM (1983) Food of walleye pollock, Theragra chalcogramma, in an embayment of southeastern Alaska. Fish Bull 81:637-642

Cooney RT, Coyle KO (1997) The role of zooplankton in the Prince William Sound ecosystem. Exxon Valdez Restoration Project Annual Report (Restoration Project 96320H). Institute of Marine Science, University of Alaska Fairbanks, Anchorage, AK, p 4-i-3-30

Costello JH, Klos E, Ford MD (1998) In situ time budgets of the scyphomedusae Aurelia aurita, Cyanea sp., and Chrysaora quinquecirrha. J Plankton Res 20:383-391

Duffy DC (1988) Predator-prey interactions between common terns and butterfish. Ornis Scand 19:160-163

Faulkenhaug T, Stabell OB (1995) Chemical ecology of predator-prey interactions in ctenophores. Mar Freshw Behav Physiol 27:249-260

Foote KG, Traynor JJ (1988) Comparison of walleye pollock target strength estimates determined from in situ measurements and calculations based in swimbladder form. J Acoust Soc Am 83:9-17

Garcia JR (1990) Population dynamics and production of
Phyllorhiza punctata (Cnidaria: Scyphozoa) in Laguna Joyuda, Puerto Rico. Mar Ecol Prog Ser 64:243-251

Graham WM (1994) The physical oceanography and ecology of upwelling shadows. PhD dissertation, University of California, Santa Cruz

Grant US, Higgens DF (1910) Reconnaissance of the geology and mineral resources of Prince William Sound, Alaska. US Geol Surv Bull 443:1-89

Greenberg N, Garthwaite RL, Potts DC (1996) Allozyme and morphological evidence for a newly introduced species of Aurelia in San Francisco Bay, California. Mar Biol 125: $401-410$

Grondahl F (1988) A comparative ecologial study on the scyphozoans Aurelia aurita, Cyanea capillata and C. larmarckii in the Gullmar Fjord, western Sweden, 1982 to 1986. Mar Biol 97:541-550

Gunderson RD (1993) Surveys of fisheries resources. John Wiley \& Sons, Inc, New York

Haldorson L, Shirley $T$, Coyle K (1998) Forage species studies in Prince William Sound. In: Duffy DC (ed) Exxon Valdez Oil Spill Restoration Project Annual Report (Restoration Project 97163 A). University of Alaska Anchorage, Anchorage, AK, p 15-49

Hamner WM (1996) Predation, cover, and convergent evolution in epipelagic oceans. In: Lenz PH, Hartline DK, Purcell JE, Macmillan DL (eds) Zooplankton: sensory ecology and physiology. Gordon and Breach Publ, Amsterdam, p $17-35$

Hamner WM, Schneider D (1986) Regularly spaced rows of medusae in the Bering Sea: role of Langmuir circulation. Limnol Oceanogr 31:171-177

Hamner WM, Hamner PP, Strand SW (1994) Sun-compass migration by Aurelia aurita (Scyphozoa): population retention and reproduction in Saanich Inlet, British Columbia. Mar Biol 119:347-356

Hansson LJ (1997) Capture and digestion of the scyphozoan jellyfish Aurelia aurita by Cyanea capillata and prey response to predator contact. J Plankton Res 19:195-208

Harbison GR (1993) The potential of fishes for the control of gelatinous zooplankton. ICES CM 1993/L:74

Hatch SA, Sanger GA (1992) Puffins as samplers of juvenile pollock and other forage fish in the Gulf of Alaska. Mar Ecol Prog Ser 80:1-14

Hay SJ, Hislop JRG, Shanks AM (1990) North Sea scyphomedusae: summer distribution, estimated biomass and significance particularly for 0-group gadoid fish. Neth J Sea Res 25:113-130

Hernroth L, Grøndahl F (1985) On the biology of Aurelia aurita (L.). 2. Major factors regulating the occurrence of ephyrae and young medusae in the Gullmar Fjord, western Sweden. Bull Mar Sci 37:567-576

Hinckley S, Bailey KM, Picquelle SJ, Schumacher JD, Stabeno PJ (1991) Transport, distribution, and abundance of larval and juvenile walleye pollock (Theragra chalcogramma) in the western Gulf of Alaska. Can J Fish Aquat Sci 48:91-98

Kendall AWJ, Schumacher JD, Kim S (1996) Walleye pollock recruitment in Shelikof Strait: applied fisheries oceanography. Fish Oceanogr 5(Suppl 1):4-18

Kikinger R (1992) Cotylorhiza tuberculata (Cnidaria: Scyphozoa)-life history of a stationary population. PSZN I: Mar Ecol 13:333-362

Kils U (1993) Formation of micropatches by zooplankton-driven microturbulences. Bull Mar Sci 53:160-169

Lagler KF, Bardach JE, Miller RR, May Passino DR (1977) Ichthyology. John Wiley \& Sons, New York

Larson RJ (1992) Riding Langmuir circulations and swimming in 
circles: a novel form of clustering behavior by the scyphomedusa Linuche unguiculata. Mar Biol 112:229-235

Larsson. P. Kleiven OT (1996) Food search and swimming speed in Daphnia. In: Lenz $\mathrm{PH}$, Hartline DK, Purcell JE, Macmillan J (eds) Zooplankton: sensory ecology and physiology. Gordon and Breach Publ, Amsterdam, p 375-387

Lebida RC, Whitmore DC (1985) Bering Sea herring aerial survey manual. Bristol Bay Data Report No. 85-2. Alaska Department of Fish and Game, Division of Commercial Fisheries, Anchorage, AK

Lenhoff HM (1964) Reversible inhibition of swimming in Stomotoca atra by mesogleal extracts of some other medusae. Biol Bull 126:115-120

Livingston PA (1993) Importance of predation by groundfish, marine mammals and birds on walleye pollock Theragra chalcogramma and Pacific herring Clupea pallasi in the eastern Bering Sea. Mar Ecol Prog Ser 102:205-215

Lucas CH, Williams JA (1994) Population dynamics of SCYphomedusa Aurelia aurita in Southampton water. J Plankton Res 16:879-895

Mackas DL, Denman KL, Abbott MR (1985) Plankton patchiness: biology in the physical vernacular. Bull Mar Sci $37: 652-674$

MacLennan DN, Simmonds EJ (1992) Fisheries acoustics. Chapman \& Hall, London

Malej A (1989) Behaviour and trophic ecology of the jellyfish Pelagia noctiluca (Forsskal, 1775). J Exp Mar Biol Ecol 126:259-270

Mansueti R (1963) Symbiotic behaviour between small fishes and jellyfishes, with new data on that between the stromateid, Peprilus alepidotus, and the scyphomedusae, Chrysaora quinquecirrha. Copeia 1963:40-80

Möller $H(1980)$ Scyphomedusa as predators and food competitors of larval fish. Kiel Meeresforschung 28:90-100

Nielsen AS, Pedersen AW, Riisgård HU (1997) Implications of density driven currents for interaction between jellyfish (Aurelia aurita) and zooplankton in a Danish fjord. Sarsia 82:297-305

Okey TA, Pauly D (1998) Trophic mass-balance model of Alaska's Prince William Sound Ecosystem, for the postspill period 1994-1996. Univ BC Fish Centre Res Rep $6: 1-144$

Olesen NJ, Frandsen K, Riisgård HU (1994) Population dynamics, growth and energetics of jellyfish Aurelia aurita in a shallow fjord. Mar Ecol Prog Ser 105:9-18

Papathanassiou E, Panayotidis P, Anagnostaki K (1987) Notes on the biology and ecology of the jellyfish Aurelia aurita Lam. In Elefsis Bay (Saronikos Gulf, Greece). PSZN I: Mar Ecol 8:49-58

Purcell JE (1985) Predation on fish eggs and larvae by pelagic cnidarians and ctenophores. Bull Mar Sci 37:739-755

Purcell JE (1997) Pelagic cnidarians and ctenophores as predators: selective predation, feeding rates and effects on prey populations. Ann Inst Oceanogr Paris 73:125-137

Purcell JE, Anderson PAV (1995) Electrical responses to water-soluble components of fish mucus recorded from

Editorial responsibility: Kenneth Sherman (Contributing Editor), Narrangansett, Rhode Island, USA the cnidocytes of a fish predator, Physalia physalis. Mar Freshw Behav Physiol 26:149-162

Schmidt GM (1977) The exchange of water between Prince William Sound and the Gulf of Alaska. Masters thesis, University of Alaska Fairbanks, Fairbanks, AK

Schneider G, Behrends G (1998) Top-down control in a neritic plankton system by Aurelia aurita medusae - a summary Ophelia 48:71-82

Shanks AL, Graham WM (1987) Orientated swimming in the jellyfish Stomolophus meleagris L. Agassiz (Scyphozoan Rhizostomida). J Exp Mar Biol Ecol 108:159-169

Simpson JH (1974) Fronts in the Irish Sea. Nature 250 404-406

Springer AM (1992) A review: walleye pollock in the North Pacific-how much difference do they really make? Fish Oceanogr 1:80-96

Stavn RH (1971) The horizontal-vertical distribution hypothesis: Langmuir circulations and Daphnia distritubions. Limnol Oceanogr 16:453-466

Stokesbury KDE, Kirsch J, Brown ED, Thomas GL, Norcross BL (2000) Seasonal variability in Pacific herring (Clupea pallasi) and walleye pollock (Theragra chalcogramma) spatial distributions in Prince William Sound, Alaska. Fish Bull US 98:400-409

Strand SW, Hamner WM (1988) Predatory behavior of Phacellophora camtschatica and size-selective predation upon Aurelia aurita (Scyphozoa: Cnidaria) in Saanich Inlet, British Columbia. Mar Biol 99:409-414

Sturdevant MV (1999) Forage fish diet overlap. Exxon Valdez Oil Spill Restoration Project Final Report (Restoration Project 96163C). Anchorage, AK, p 1-102

Sullivan BK, Garcia RJ, Klein-MacPhee G (1994) Prey selection by the scyphomedusan predator Aurelia aurita. Mar Biol 121:335-341

Tankersley RA, McKelvery LM, Forward RB Jr (1995) Responses of estuarine crab megalopae to pressure, salinity and light: implications for flood tide transport. Mar Biol 122:391-400

Toyokawa M. Inagaki T, Terazaki M (1997) Distribution of Aurelia aurita (Linnaeus, 1758) in Tokyo Bay; observations with echosounder and plankton net. Proceedings of the 6th International Conference on Coelenterate Biology. Natuurhistorisch Museum, Leiden, p 483-490

van Hyning JM, Cooney RT (1974) Association of walleye pollock, Theragra chalcogramma, with the jellyfish, Cyanea. Copeia 1974:791

Wooldridge T, Erasmus T (1980) Utilization of tidal currents by estuarine zooplankton. Estuar Coast Mar Sci 11:107-114

Wrobel D, Mills C (1998) Pacific coast pelagic invertebrates: a guide to the common gelatinous animals. Monterey Bay Aquarium, Monterey, CA

Yasuda T (1969) Ecological studies on the jelly-fish, Aurelia aurita, in Urazoko Bay, Fukui Prefecture. I. Occurrence pattern of the medusa. Bull Jpn Soc Sci Fish 35:1-6

Zar JH (1984) Biostatistical analysis. Prentice-Hall, Englewood Cliffs, NJ

Submitted: April 25, 1999; Accepted: October 14, 1999

Proofs received from author(s): March 17, 2000 